Seminário de Pesquisa

Programa de Pós-Graduação

Design FAU USP

\title{
Procedimentos e Técnicas de pesquisa no setor joalheiro
}

\author{
Claudia Dayé, Clice de Toledo Sanjar Mazzilli \\ design de joias; semântica da joia; técnicas de pesquisa; \\ procedimentos de pesquisa
}

Este projeto tem como propósito investigar a produção joalheira no Brasil no aspecto da sintaxe, semântica e simbologia do produto, concebendo a perspectiva não somente do projeto (do designer) como também de seu uso (do consumidor), constituindo uma abordagem de investigação da linha de pesquisa de Processos e Linguagens. Os métodos utilizados serão a revisão bibliográfica de autores como Klaus Krippendorff, Jean Baudrillard e Bernhard E. Bürdek e a pesquisa de campo. No momento presente, a pesquisa se encontra na fase bibliográfica. Por meio de pesquisa qualitativa

Curso

Mestrado

\section{Linha de Pesquisa}

Design: Processos e Linguagens

\section{Claudia Dayé}

Mestranda no Programa de Pós-Graduação em Design pela Faculdade de Arquitetura e Urbanismo da Universidade de São Paulo, FAUUSP. Publicitária com especialização em Design Gráfico. Experiente na área de Comunicação, pesquisadora da joalheria brasileira, autora do livro "Joalheria no Brasil".

e-mail: claudiad@usp.br

Lattes: http://lattes.cnpq. br/9216245770471489

\section{Clice de Toledo Sanjar Mazzilli}

Graduada em Arquitetura e Urbanismo pela FAU-USP (1984), onde realizou mestrado (1993), doutorado (2003) e livre-docência (2015) em Programação Visual. Leciona no Departamento de Projeto da FAU-USP, desde 2001 e coordena o Programa de Pós-graduação em Design e o Laboratório de Programação Gráfica.

e-mail: clice@usp.br

Lattes: http://lattes.cnpq. br/9635315172253349

Orcid: https://orcid.org/00000002-6903-9099 semiestruturada, serão verificados os parâmetros adotados por designers de joias na elaboração de seus projetos, e investigada a percepção de usuários em torno de sua estética. A coleta de dados por entrevistas tem como objetivo detectar percepções, significados, preferências, avaliações e adaptações. 0 estudo de suas análises abordará características individuais, sociais e culturais, a psicologia comportamental, linguagem e percepção de produtores e compradores, em amostra extraída do mercado de joias, em diferentes polos industriais joalheiros: São Paulo, Rio de Janeiro, Minas Gerais, Rio Grande do Sul, Pará e Amazônia. Devido à pandemia, as entrevistas que seriam presenciais serão aplicadas via computador e joias que seriam mostradas ao vivo serão substituídas por fotografias. Na entrevista, além das fotos e do roteiro de perguntas, será aplicada a técnica de diferenciais semânticos, com o uso de placas. Se o recurso online por um lado é limitador e desafiador, por outro permite a coleta de dados em diferentes cidades do país, o que exemplifica como é necessário a discussão de procedimentos e técnicas de pesquisa neste momento. 


\title{
Research procedures and techniques in the jewellery sector
}

\author{
Claudia Dayé, Clice de Toledo Sanjar Mazzilli
}

\author{
jewelry; jewelry design; jewel semantics; research techniques; \\ research procedures
}

This project aims to investigate the jewelry production in Brazil in terms of syntax, semantics and symbolism of the product, understood as a designed product, from the point of view of the author, and also by its use, from the perspective of the consumer, constituting an approach in the line bias of the research field of Processes and Languages. The methods used will be based on the literary review of authors such as Klaus Krippendorff, Jean Baudrillard and Bernhard E. Bürdek, and on field research. At the present time, the research is in the phase of bibliographic review. Through research of the semi-structured qualitative kind, the parameters adopted by studied jewelry designers in the elaboration of their projects will be verified, and the perception raised by users around their aesthetics will be investigated. Collection of data extracted from interviews aims to detect elements such as perceptions, meanings, preferences, assessments and adaptations. The study of its analyses aims to address individual, social and cultural characteristics, behavioral psychology, language and perception of producers and buyers, based in a sample extracted from the market of jewellery, and in different industrial jewellery hubs located São Paulo, Rio de Janeiro, Minas Gerais, Rio Grande do Sul, Pará and the Amazon. Due to the pandemic, the interviews originally planned to be accomplished personally will be applied via online conference platforms, and the jewellery that would be presented as an object will be replaced by photographs. In addition to the photos and the questions structured in the script, the interview will also count on the application of the technique of semantic differential technique, with the use of sign boards. If, on one hand, the online resource presents particular limitations and challenges, on the other hand it allows for data collection in different cities of the country, and will exemplify how necessary it is to discuss the research procedures and techniques at this time.

\section{Clice de Toledo Sanjar Mazzilli}

Graduated in Architecture and Urbanism at FAU-USP (1984), where she completed her Master's (1993), PhD (2003) and PhD (2015) in Visual Programming. She has taught at the Design Department at FAU-USP since 2001. Coordinates the Postgraduate Program in Design and the Graphical Programming Laboratory.

e-mail: clice@usp.br

Lattes: http://lattes.cnpq. $\mathrm{br} / 9635315172253349$

Orcid: https://orcid.org/00000002-6903-9099

\section{Referências | References}

BAUDRILLARD, J. 1975. O sistema dos objetos. São Paulo: Perspectiva.

BÜRDEK, B. E. 2010. Design: História, teoria e prática do design de produtos. São Paulo: Blucher.

KRIPPENDORFF, K. \& VAKEVA, S. 1989. The Language of Objects. Blueprint (58): 52. 〈http://repository.upenn.edu/asc_papers/215〉, 20/07/2020. 